\title{
Syntrophic microbial system for $e x$-situ degradation of paddy straw at low temperature under controlled and natural environment
}

\author{
Livleen Shukla ${ }^{1}$, Archna Suman $^{1}$, Priyanka Verma ${ }^{1}$, Ajar Nath Yadav ${ }^{1,2}$, Anil Kumar Saxena ${ }^{1,3}$ \\ ${ }^{1}$ Division of Microbiology, Indian Agricultural Research Institute, New Delhi-110012, India. \\ ${ }^{2}$ Department of Biotechnology, Akal College of Agriculture, Eternal University, Sirmour-173101, India. \\ ${ }^{3}$ National Bureau of Agriculturally Important Microorganisms, Mau-275101, India.
}

\section{ARTICLE INFO}

Article history:

Received on: $28 / 02 / 2016$

Revised on: 19/03/2016

Accepted on: 11/04/2016

Available online: 21/04/2016

Key words:

Agriculture waste,

Composting, Microbial

consortia, Psychrotrophic

microbes

\begin{abstract}
The syntrophic microbial application for lignocellulosic biodegradation and subsequent transformation into compost provides an alternative strategy against burning and disposing post harvested agricultural biomass which is of vital importance in agriculture used as compost. Biodegradation process is hindered during winter season, as the microorganisms involved in lignocellulose biodegradation slows down their metabolism due to unfavourable growth conditions at low temperatures. In order to intensify the composting process at low temperature, psychrotrophic microbes were isolated and characterized for lignocellulosic hydrolytic potential specifically at low temperatures. Among the isolated microbes, four efficient lignocellulolytic psychrotrophic microbes (Eupenicillium crustaceum, Paceliomyces sp., Bacillus atropheus and Bacillus sp.) and commercial fungal consortia (Aspergillus awamori, Aspergillus nidulans, Trichoderma viride and Phanerochaete chrysosporium) were used in present study. It was found that psychrotrophic microbes along with the commercial fungal consortium enhanced the composting process at low temperature. These psychrotrophic and mesophilic microbial consortium can be used for degradation of agri-residues and conversion to a value added product like compost, which helps in enhancing soil fertility and decreasing environmental pollution caused by burning of agrowastes. This is the first report for biodegradation of paddy straw by psychrotrophic microbes at low temperatures.
\end{abstract}

\section{INTRODUCTION}

Lignocellulosic biomass is renewable and can be degraded by microorganisms, which is one of the most abundant resources in the world. Agricultural waste products such as paddy straw and paddy husk are important sources of lignocellulosic biomass. Rice is India's pre-eminent crop, and is the staple food of the people of the eastern and southern parts of the country. India is one of the world's largest producers of rice, accounting for $20 \%$ of all world rice production. Total rice production was 157.5 million tons in 2014-15 (http://oryza.com). About 1.35 tons of rice straw remains in the field from every ton of harvested rice grain [1]. The disposal of rice straw is a problem due to the huge bulk material, slow degradation rate and harboring of diseases. It cannot be used as animal feed due to its

* Corresponding Author

Archna Suman, Division of Microbiology, Indian Agricultural Research Institute, New Delhi-110012, India. Email: archsuman@yahoo.com;

Phone: +91-9873755010, Fax: +91-11-25846420 low digestibility, low protein, high lignin and silica content. Burning of rice straw increases total organic carbon in aerosols and it results in the emission of poisonous gasses such as methane, carbon monoxide, carbon dioxide and nitrous oxide, which have both ecological and environmental implications [2]. Rice straw compost is most commonly applied to paddy fields in Japan to improve soil fertility and increase yield [3].

Microbial composting is one of the up-coming technologies for agricultural wastes disposal in which biodegradation of lignocellullosic matter like paddy straw is carried out using efficient complex microbial communities of ligninolytic and cellulolytic microorganisms.

The recycling of waste through composting reduces disposal of organic wastes and it would be applicable to soil allows cultivation in places where soil is a limiting factor and improves the quality of crop by providing nutrients $[4,5]$. There are many reports on biodegradation of paddy straw using microbial consortium consisting fungi, actinobacteria but no reports are available for biodegradation of paddy straw using psychrotrophic microbes at low temperature [6-8]. 
As microbial population dynamics is highly influenced by varying temperature regimes. Temperature is an important factor in composting of paddy straw during winter seasons. Microbial degradation of paddy straw has shown conversion of 60$70 \%$ carbon to carbon dioxide [9]. The degradation is slowed down during the severe low temperatures prevailing during the winter seasons. Temperature being a significant factor during composting, determines the role of various biological processes including microbial succession [10]. At low temperature the metabolism of the stated mesophilic microorganisms is intensely affected which could be mitigated by use of psychrotrophic lignocellulolytic microorganisms to colonize composting substrates which substantially creates an environment for prolific the growth and activity of the potent mesophilic microbes.

In the present investigation, psychrotrophic microbes were isolated, identified using $16 \mathrm{~S} / 18 \mathrm{~S}$ rRNA gene sequencing and characterized for lignocellulolytic activities. These psychrotrophic bacteria and fungi were co-inoculated with mesophilic fungi for intensifying paddy straw composting at low temperatures. The quality of the compost was assayed by analyzing various physical, chemical and biological parameters, which included $\mathrm{pH}$, electrical conductivity, $\mathrm{C} / \mathrm{N}$ ratio, humus content, microbial activity and germination index.

\section{MATERIALS AND METHODS}

\subsection{Microorganisms and lignocellulosic material}

Water, soil and sediment samples were collected from different sites of cold deserts of NW Himalayas, which includes Rohtang Pass $\left(32^{\circ} 22^{\prime} 17^{\prime \prime} \mathrm{N}: 77^{\circ} 14^{\prime} 47^{\prime \prime} \mathrm{E}\right)$, Khardungla Pass $\left(34^{\circ}\right.$

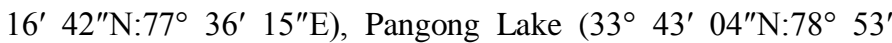
$\left.48^{\prime \prime} \mathrm{E}\right)$ and Dashair Lake ( $\left.32^{\circ} 22^{\prime} \quad 17^{\prime \prime} \mathrm{N}: 77^{\circ} 1^{\prime} 4^{\prime} \quad 47^{\prime \prime} \mathrm{E}\right)$. Psychrotrophic microbes were isolated through enrichment using the standard serial dilution plating technique. One gram of sediment/soil or $1 \mathrm{~mL}$ of water sample was added to $9 \mathrm{~mL}$ of sterile distilled water. The samples were then diluted and appropriate dilutions were spread on nutrient agar, R2A medium, tryptic soy agar and potato dextrose agar (HiMedia Laboratories,
Mumbai, India) and plates were incubated at $4-10{ }^{\circ} \mathrm{C}$ for $7-15$ days [11]. Colonies that appeared were purified by repeated streaking to obtain isolated colonies using nutrient agar and potato dextrose agar plates. The pure cultures were maintained at $4{ }^{\circ} \mathrm{C}$ as slant and glycerol stock $(20 \%)$ at $-80{ }^{\circ} \mathrm{C}$ for further use. All the isolates were screened for tolerance to temperatures and $\mathrm{pH}$ as method described earlier [12]. Lignocellulose degrading commercial fungal strains: Aspergillus awamori NCIM 1188, Aspergillus nidulans ITCC-2011, Trichoderma viride ITCC-2211 and Phanerochaete chrysosporium NCIM-1073 were obtained from the culture collection from the Division of Microbiology, Indian Agricultural Research Institute, New Delhi (Table 1). Paddy straw was obtained from FOSU (Farms Operation Service Unit), Indian Agricultural Research Institute, New Delhi.

\subsection{Screening of isolates for lignocellulolytic activity}

Isolates were initially screened for qualitative production of extracellular hydrolytic enzymes. In the qualitative screening, the utilization of different substrates by various isolates was studied as indication of enzyme production. Hydrolytic enzyme activities of isolates were tested on diffusion agar plate of basal medium ( $1 \mathrm{~g}$ yeast extract, $1 \mathrm{~g} \mathrm{KH}_{2} \mathrm{PO}_{4}, 0.1 \mathrm{~g} \mathrm{MgSO}_{4} .7 \mathrm{H}_{2} \mathrm{O}, 0.05$ $\mathrm{g} \mathrm{CaCl}_{2} \cdot \mathrm{H}_{2} \mathrm{O}, 5 \mathrm{~g} \mathrm{NaCl}, 1 \mathrm{~g} \mathrm{NaCO}_{3}$ and $18 \mathrm{~g}$ agar per liter) supplemented with different substrates such as xylan $(0.1 \%)$ and carboxy methyl cellulose $(0.5 \%)$. Purified microbes were grown in $150 \mathrm{~mL}$ flasks containing $50 \mathrm{~mL}$ of nutrient broth or potato dextrose broth and $5 \mu \mathrm{L}$ of culture was spot inoculated on diffusion agar plate of basal medium and incubated at 4 and $10{ }^{\circ} \mathrm{C}$ for 3-5 days. The clear zone around the colony was observed in plates flooded with $0.1 \%$ Congo red solution for $15 \mathrm{~min}$ at room temperature followed by further treatment with $1 \mathrm{M} \mathrm{NaCl}$ for cellulase and xylanase activity $[13,14]$. The xylanase and cellulase (FPase, CMCase, and $\beta$-glucosidase) activity of the enzyme was determined using DNS method in $50 \mathrm{mM}$ citrate-phosphate buffer (pH 6.5) containing $1 \%(\mathrm{w} / \mathrm{v})$ of each substrate [15]. Stability of enzymes was tested as described earlier by Yadav et al. [16] and the reactions were conducted with paddy straw as described earlier [17].

Table 1: Enzyme activities of microbes used in composting of paddy straw at low temperatures

\begin{tabular}{|c|c|c|c|c|c|}
\hline \multirow{2}{*}{ Composting strains } & \multirow{2}{*}{ Strain no } & \multicolumn{4}{|c|}{ IU $\mathrm{mg}^{-1}$ protein } \\
\hline & & FPase & CMCase & Xylanase & Cellobiose \\
\hline \multicolumn{6}{|l|}{ Mesophilic Fungi } \\
\hline Aspergillus awamori & NCIM 1188 & 7.15 & 5.56 & 2.63 & 1.15 \\
\hline Aspergillus nidulans & ITCC 2011 & 5.26 & 42.36 & 33.62 & 15.26 \\
\hline Phanerochaete chrysosporium & ITCC 2211 & 8.26 & 28.26 & 23.36 & 11.35 \\
\hline Trichoderma viride & NCIM 1073 & 12.05 & 43.55 & 31.25 & 16.36 \\
\hline \multicolumn{6}{|l|}{ Psychrotrophic Fungi } \\
\hline Eupenicillium crustaceum & IARI-L-88 & 13.16 & 28.14 & 28.06 & 11.23 \\
\hline Paceliomyces sp. & IARI-LF-23 & 15.41 & 32.52 & 26.19 & 5.89 \\
\hline \multicolumn{6}{|l|}{ Psychrotrophic Bacteria } \\
\hline Bacillus atropheus & IARI-E & 24.83 & 34.63 & 28.32 & 10.25 \\
\hline Bacillus sp. & IARI-A & 10.06 & 31.14 & 37.71 & 15.26 \\
\hline
\end{tabular}




\subsection{Molecular identification of microbial isolates}

Isolation of genomic DNA was carried out as method described earlier by Verma, et al. [18]. The extracted DNA was used as the template for PCR amplification of the 16S and 18S rRNA gene using universal $16 \mathrm{~S}$ rRNA gene primers [pA (5'AGAGTTTGATCCTGGCTCAG-3') and ${ }^{\prime}$ pH (5'AAGGAGGTGATCCAGCCGCA $-3^{\prime}$ )] and 18S rRNA gene primers [ITS1F (5'-TCCGTAGGTGAACCTGCGG-3') and ITS2 (5'-TCCTCCGCTTATTGATATGC- $\left.3^{\prime}\right)$ ] for bacterial and fungal isolates respectively. The amplification conditions for bacteria were used as described earlier by Yadav, et al. [19] and for fungal the amplification condition was used as: $95{ }^{\circ} \mathrm{C}$ for $15 \mathrm{~min}$, followed by 40 cycles at $95{ }^{\circ} \mathrm{C}$ for $1 \mathrm{~min}, 53{ }^{\circ} \mathrm{C}$ for $30 \mathrm{sec}, 72^{\circ} \mathrm{C}$ for $1 \mathrm{~min}$, and final elongation of $95{ }^{\circ} \mathrm{C}$ for $8 \mathrm{~min}$. The $16 \mathrm{~S} / 18 \mathrm{~S}$ rRNA gene was sequenced by Xcelris Labs (Ahmedabad, India) using Sanger's di-deoxy nucleotide sequencing method. A similarity search for the sequence was carried out using the BLAST program of the National Centre of Biotechnology Information (http://www.ncbi.nlm.nih.gov/). The phylogenetic tree was constructed on the aligned datasets using the Maximum likelihood method implemented in the program MEGA 4.0.2. Bootstrap analysis was performed on 1000 random samples taken from the multiple alignments [20]. The partial 16S/18S rRNA gene sequences were submitted to NCBI GenBank and the assigned accession numbers were JF343216, KF530858, KF650699 and KF650701.

\subsection{Experimental set up}

All the selected cultures were tested for their compatibility with each other. They were co-inoculated on potato dextrose agar plate and incubated at $30{ }^{\circ} \mathrm{C}$ for 2-3 days. None of the culture inhibited the growth of other culture, but grew well. Jaggery medium was used for mass culture of all the fungi, whereas nutrient broth was used for mass culture of bacteria [21]. After incubation fungal spores and mat were harvested by breaking the mycelial mat through a blender and mixing the strains.

Experiments were set up under controlled condition in small trays in incubator at $10{ }^{\circ} \mathrm{C}$ with $55 \%$ relative humidity for optimization of inoculums dose. Paddy straw (200g) was taken as the substrate and humified with $100 \mathrm{~mL}$ sterile distilled water, which following microbial inoculation (Table 2). Sterilized urea with $0.2 \mu \mathrm{m}$ nylon membrane filter through vacuum filtration was applied as nitrogen amendment.

Composting experiment was carried in cemented pits at the Division of Microbiology, Indian Agricultural Research Institute, New Delhi, during the winter season from December to February for upgrading the final technology for paddy straw degradation (large scale $1000 \mathrm{~kg}$ ). Paddy straw taken as the substrate for microbial action was added to the pits $(6 \times 4 \times 2)$ meter and humified to $100 \%$ using water. Following this, various amendments were performed as mentioned in Table 2. The material in pits was mixed manually at equal intervals of 30 days to replenish oxygen concentration and the sampling for biochemical and chemical parameters was done in 30,60 and 90 days.

Table 2: Treatments for optimization of lignocelluloses degradation of paddy straw .

\begin{tabular}{lll}
\hline \multicolumn{2}{c}{ Environment } & \multicolumn{1}{c}{ Treatment Details } \\
\cline { 1 - 2 } Control & \multicolumn{1}{c}{ Natural } & \\
T1 & P1 & PS (control) \\
T2 & & PS + 1\% Urea \\
T3 & & PS + 1\% Urea + BC \\
T4 & & PS +1\% Urea + FC \\
T5 & P2 & PS + 1\% Urea + CFC \\
T6 & P3 & PS + + 1\% Urea + BC + FC \\
T7 & & PS + BC \\
T8 & & PS + BC \\
T9 & P4 & PS + CFC + FC + CFC \\
T10 & P5 & PS + BC + FC \\
T11 & PS + BC+ FC + CFC \\
T12 & &
\end{tabular}

$P S$, Paddy Straw; $B C$, Bacterial Consortia; $F C$, Fungal Consortia; $C F C$, Commercial fungal consortia;

FC-(IARI-L-88 and IARI-LF-23); BC-(IARI-E and IARI-A); CFC-(NCIM 1188, ITCC-2011, ITCC-2211 and NCIM-1073)

\subsection{Determination of enzymatic activity}

Filter-paper activity (FPAase), carboxymethyl cellulase (CMCase) and xylanase enzyme were extracted from compost with citrate buffer of $\mathrm{pH} 7$. The $0.5 \mathrm{~mL}$ of filtrate was incubated with respective substrates (filter paper strips/cellobiose/xylan) and volume was made up to $1 \mathrm{~mL}$ with $0.05 \mathrm{M}$ citrate buffer of $\mathrm{pH} 4.8$. All the tubes were incubated at $50{ }^{\circ} \mathrm{C}$ for $1 \mathrm{~h}$ for cellulase and 30 min for cellobiase and xylanase. Reducing sugars liberated by action of enzyme was estimated as described earlier [17]. Enzyme concentration was represented as international unit (IU) per gram of substrate. One IU is defined as one mol of product produced in one minute from one gram of substrate.

\subsection{Chemical analysis of compost}

Temperature was monitored continuously using a dial thermometer. Ambient temperature was collected from data station in the meteorological laboratory of Indian Agricultural Research Institute, New Delhi. Electrical conductivity (EC) and $\mathrm{pH}$ were measured. $10 \mathrm{~g}$ of sample was mixed with distilled water in the ratio 1:2.5 and stirred in magnetic stirrer for $20 \mathrm{~min}$. After settling of the solid matters, electrical conductivity and $\mathrm{pH}$ was recorded using conductivity and $\mathrm{pH}$ meter respectively. Organic carbon was determined according to Walkley and Black's rapid titration method [22]. Total nitrogen (\%) was analyzed using kjeldahl's procedure by N-analyzer UDK-149 (VELP Scientifica srl, Italy).

Total humus content was extracted by shaking the composting sample with alkaline sodium pyrophosphate (a mixture of $0.1 \mathrm{M}$ $\mathrm{NaOH}$ and $0.1 \mathrm{M}$ sodium pyrophosphate) in the ratio of 1:5 for 1$2 \mathrm{~h}$ on shaker. The contents were allowed to stand overnight and centrifuged at $10,000 \mathrm{~g}$ for $10 \mathrm{~min}$. The dark brown colour solution was dialyzed in the dialyzing tubes under running water for $24 \mathrm{~h}$. The total amount of humic and fulvic acid present in the solution was estimated as method described by Black, et al. [23]. For germination assay, the Petri dishes $(10 \mathrm{~cm}$ diameter) were 
lined with Whatman No.1 filter paper and $5 \mathrm{~mL}$ of the sample supernatant was added. In each of the plates, 10 seeds (Lepidium sativum L.) were shown, incubated at room temperature and analysed after 48 hours. Number of seeds germinated on the filter paper was recorded and root length measured. Seeds germinated in distilled water served as control. Germination index was calculated as described by Zucconi, et al. [24].

\section{RESULTS AND DISCUSSION}

\subsection{Isolation, identification and characterization of psychrotrophic microbes}

Total 65 bacteria and 27 fungi were isolated from cold deserts of north western Indian Himalayas and characterized for temperatures and $\mathrm{pH}$. All microbes were screened in-vitro for extracellular hydrolytic enzymes production using plate assays. Among 92 microbes, two psychrotrophic fungi (IARI-L-88 and IARI-LF-23) and two psychrotrophic bacteria (IARI-E and IARIA) showing efficient lignocellulolytic activities were selected for present investigation.

The partial 16S/18S rRNA gene sequences of positive bacterial and fungal isolates were sequenced and IARI-L-88, IARI-LF-23, IARI-E and IARI-A was identified as Eupenicillium crustaceum, Paceliomyces sp., Bacillus atropheus and Bacillus sp. respectively. The phylogenetic analysis based on 16S/ 18S rRNA gene sequences were constructed using MEGA 4.02 software (Fig .1).

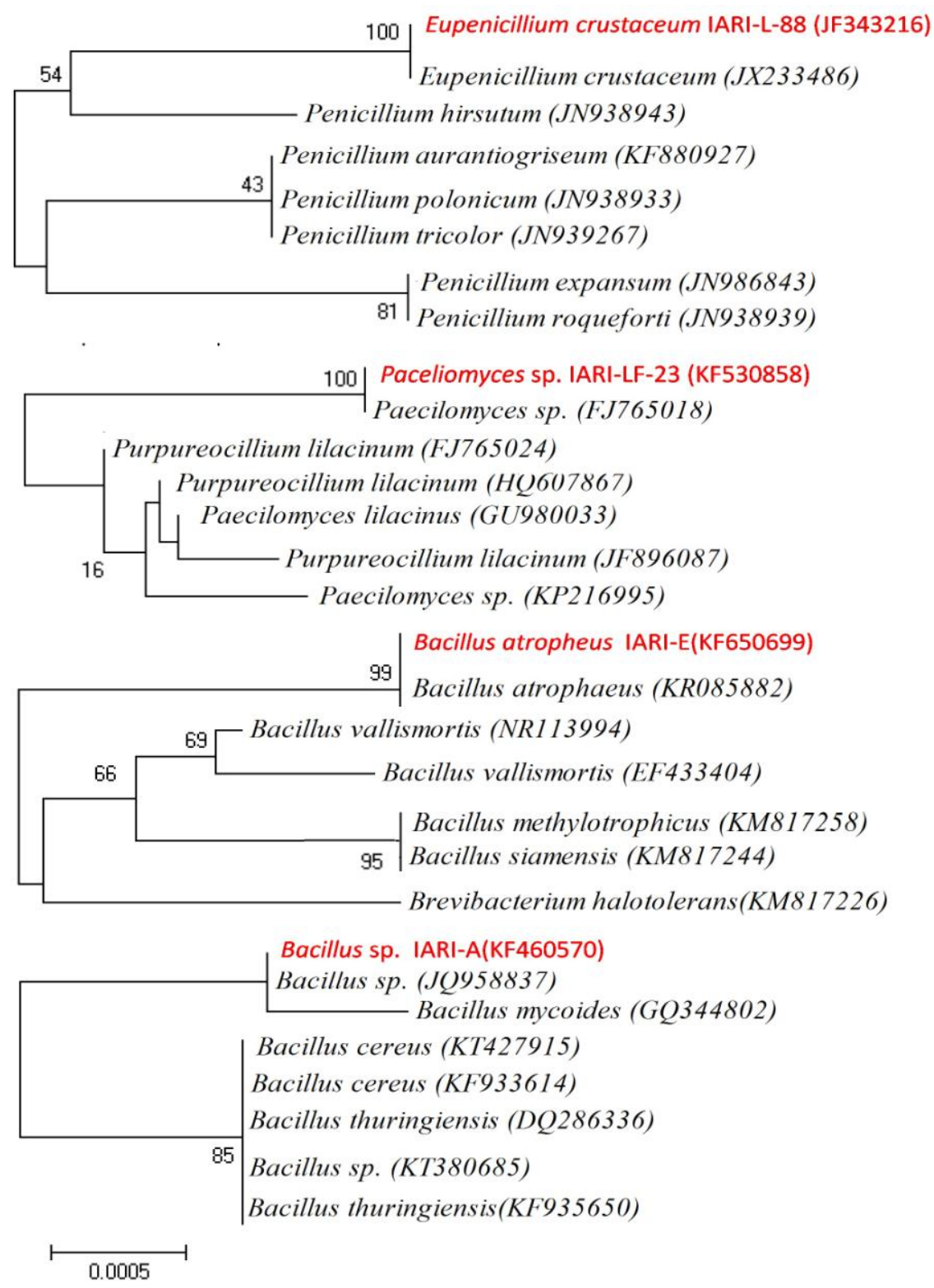

Fig. 1 Phylogenetic tree showing the relationship psychrotrophic microorganisms, 16S/28S rRNA gene sequences with reference sequences obtained through BLAST analysis. The sequence alignment was performed using the CLUSTAL W program and trees were constructed using Neighbor joining with algorithm using MEGA4 software (Tamura et al. 2007). 


\subsection{Lignocellulolytic activity}

The psychrotrophic fungi (Eupenicillium crustaceum, Paceliomyces sp.), psychrotrophic bacteria (Bacillus atropheus and Bacillus sp.) and mesophilic fungi (Aspergillus awamori, Aspergillus nidulans, Trichoderma viride and Phanerochaete chrysosporium) show efficient lignocellulolytic activities (Table 1).

\subsection{Evaluation for biodegradation of paddy straw}

Psychrotrophic and mesophilic microbes were studied for composting paddy straw under controlled condition at $10^{\circ} \mathrm{C} .200 \mathrm{~g}$ of chopped paddy straw were taken in small plastic trays as composting substrate and ten treatments (Table 2). The commercial fungal consortia (CFC), fungal consortia (FC) and bacterial consortia (BC) were taken in 1:1:1:1 for EFC, 1:1 for FC and 1:1 for BC respectively. Urea was used as nitrogen sources. Composting of paddy straw under control condition estimated in term of hydrolytic enzymes production by different microbial consortia (Fig. 2). Among different treatment T7 (PS $+1 \%$ Urea + $\mathrm{BC}+\mathrm{FC}+\mathrm{EFC}$ ) showed highest production of CMCase, xylanase, FPase and cellobiase, followed by T6 $(\mathrm{PS}+1 \%$ Urea+BC+FC). Result show different enzymes production in $\mathrm{T} 7>\mathrm{T} 6>\mathrm{T} 12>\mathrm{T} 11$, hence these treatments were selected for further upscaling the degradation of paddy straw at low temperatures in cemented pits during winter season. After optimization, the treatments were designed for scaling up the composting process under natural conditions at low temperature during winter seasons conducted in cemented pits (Table 2). During composting process, temperature is a function of the accumulation of heat generated metabolically and the rise in temperature is a determinant of microbial activity [25]. The thermophilic phase started after $48 \mathrm{~h}$ of biodegradation as the temperature record showed a rise in its values and reflected rapid initiation of composting process (Fig. 3). The peak temperature inside the composting pits (P1-P5) ranged between 22 and $27{ }^{\circ} \mathrm{C}$ for 48 days. Thereafter, the temperature of composting mixtures decreased and fluctuated between 21 and $18{ }^{\circ} \mathrm{C}$ for 90 days of composting. This revealed that though the organic matter was partially stabilized but still under the attack of microorganisms. The temperature of P2-P5 composts stabilized at $19{ }^{\circ} \mathrm{C}$ on 80 day. The temperature decrease was attributed to depletion of easily available organic nutrients and stability of the composted product. However, P1 compost showed little higher temperature $\left(22{ }^{\circ} \mathrm{C}\right)$, indicating instability and immaturity of compost.
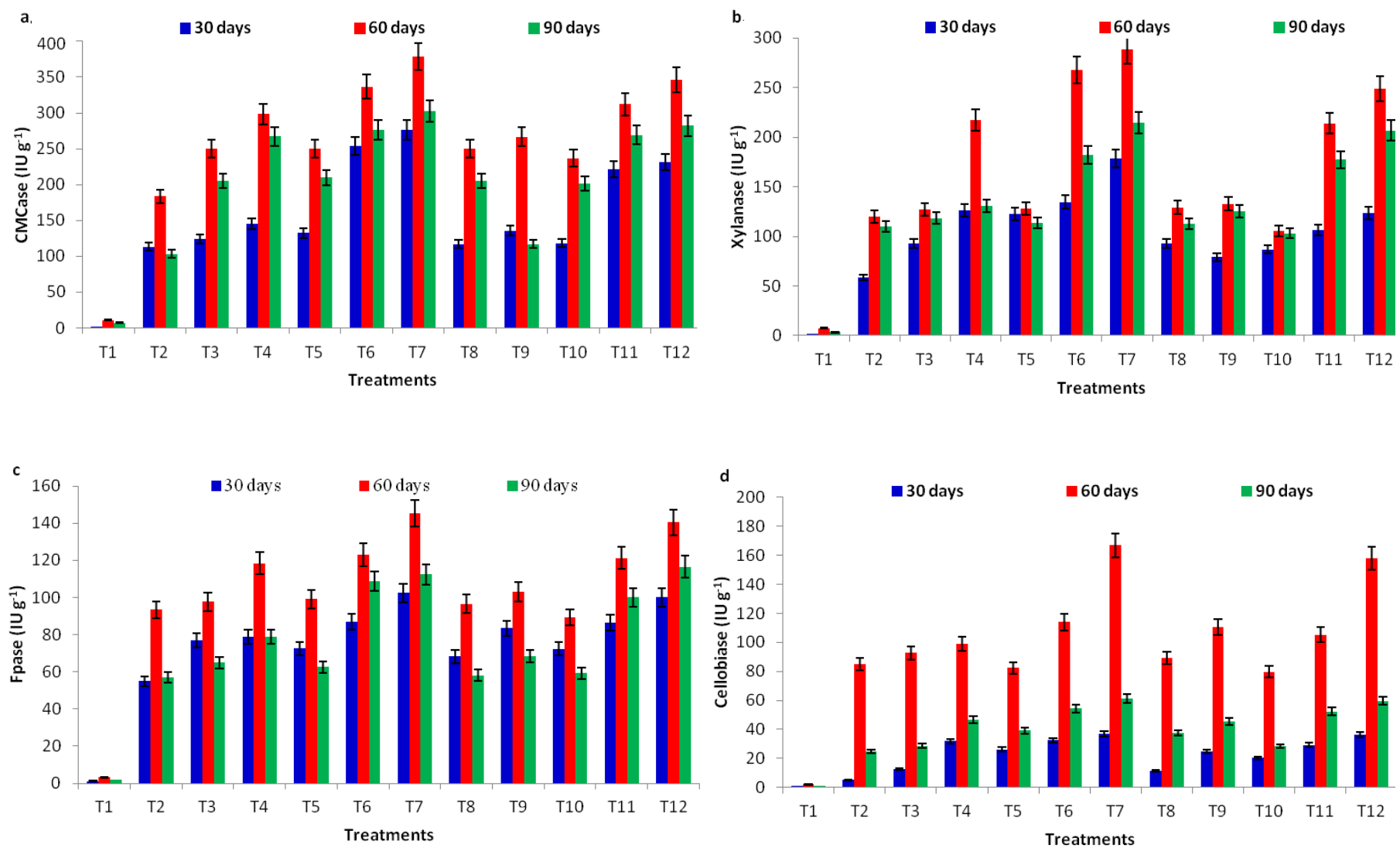

Fig. 2 Hydrolytic enzymes activity in compost affected by microbial consortia, a. CMCase; b. Xylanase; c. FPase; d. Cellobiase 


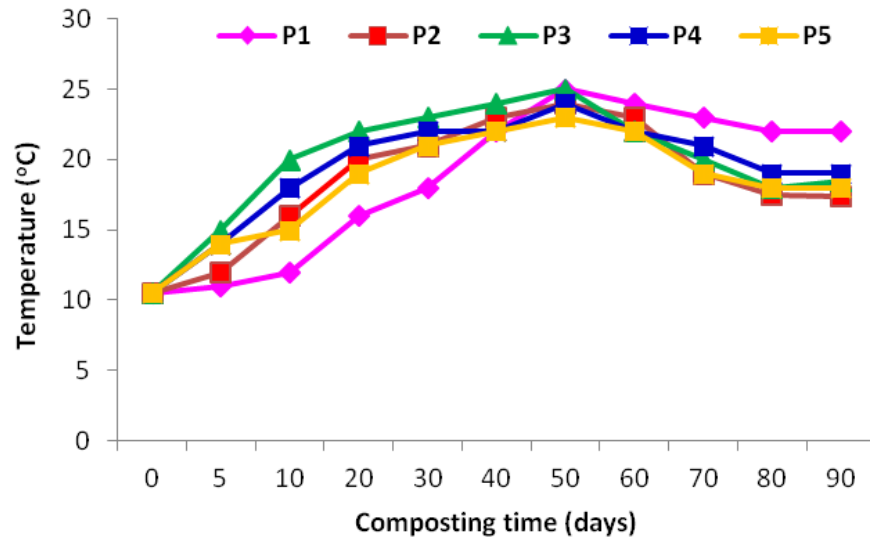

Fig. 3 Changes in temperature during composting of paddy straw.

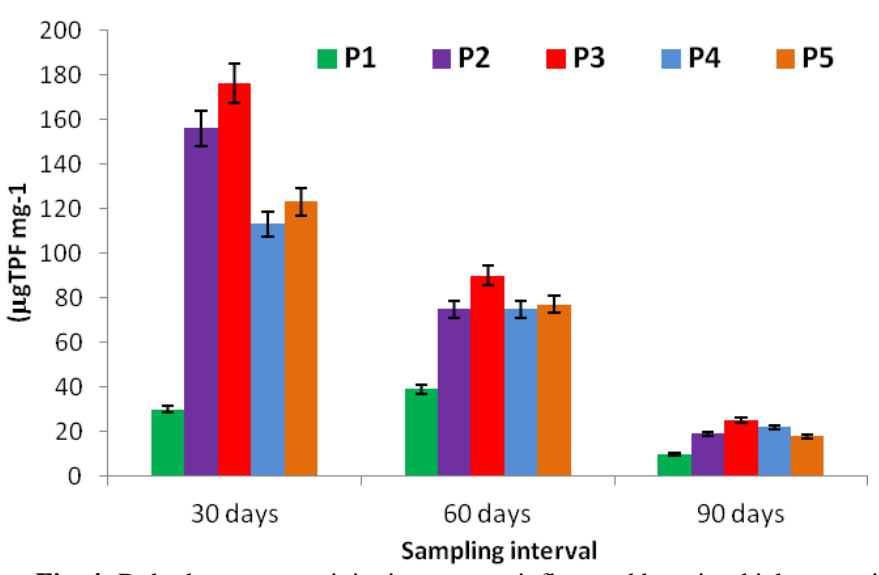

Fig. 4: Dehydrogenase activity in compost influenced by microbial consortia.

Table 3: Properties of different composts at the Initial and final (after 90 days) of composting process.

\begin{tabular}{|c|c|c|c|c|c|c|c|c|c|c|}
\hline S. No. & Time & EC & pH & OM \% & $\mathrm{C}_{\mathrm{T}} \%$ & $\mathrm{C} / \mathrm{N}$ & $\% \mathrm{GI}$ & HA & FA & Av. $P$ \\
\hline \multirow{2}{*}{ P1 } & Initial & 2.5 & 7.3 & 63.5 & 38.5 & 47.8 & - & - & - & 25 \\
\hline & Final & 2.4 & 7.4 & 62.5 & 37.5 & 46.5 & 95 & 2.5 & 5 & 225 \\
\hline \multirow{2}{*}{$\mathrm{P} 2$} & Initial & 2.4 & 7.4 & 65.5 & 38.5 & 45.6 & - & - & - & 65 \\
\hline & Final & 1.6 & 8.2 & 52.5 & 32.5 & 18.5 & 160 & 17 & 11 & 556 \\
\hline \multirow{2}{*}{ P3 } & Initial & 2.4 & 7.4 & 65.5 & 38.5 & 45.8 & - & - & - & 70 \\
\hline & Final & 1.4 & 8.4 & 45.2 & 25.5 & 15.6 & 175 & 25 & 17 & 665 \\
\hline \multirow{2}{*}{ P4 } & Initial & 2.4 & 7.4 & 65.5 & 38.5 & 45.6 & - & - & - & 65 \\
\hline & Final & 1.6 & 8.1 & 54.2 & 32.2 & 20.2 & 145 & 22 & 15 & 558 \\
\hline \multirow{2}{*}{ P5 } & Initial & 2.5 & 7.5 & 65.5 & 38.5 & 45.7 & - & - & - & 72 \\
\hline & Final & 1.7 & 7.9 & 49.5 & 28.5 & 19.8 & 150 & 19 & 14 & 612 \\
\hline
\end{tabular}

EC, Electrical conductivity; OM, Organic matter; $\mathrm{C}_{\mathrm{T}}$, Total carbon; GI, Germination index, HA, Humic acid; FA, Fulvic acid; Av P, Available P

\subsection{Chemical analysis of compost}

A comparison of $\mathrm{pH}$ measured in the interval of 30 days for over a period of ninety days (Table 3). The $\mathrm{pH}$ values of composts were near neutral to alkaline. Treatment P3 showed highest range of $\mathrm{pH}$ from initial to final (7.78 to 8.4). The high $\mathrm{pH}$ values may be due to mineralization of organic $\mathrm{N}$ to $\mathrm{NH}_{4}$ [26]. The consortia having more number of fungal isolates recorded relatively low $\mathrm{pH}$ values. The $\mathrm{EC}$ value decreases as the composting process continues because soluble compounds are consumed as nutrients by microorganisms, and some compounds, such as ammonia and mineral salts, are volatilized or precipitated. Lower EC value of compost shows lack of availability of minerals, while higher value of EC inhibits biological activity [27]. An EC of less than $1.5 \mathrm{dSm}^{-1}$ is acceptable for mature compost to be used as soil amendment [28]. The treatment P3 demonstrated a lower $\mathrm{EC}$ value as compared to other treatments.

Mineralization of organic residues and volatilization of nitrogen as ammonia narrows the $\mathrm{C} / \mathrm{N}$ ratio. The greater the narrowing of $\mathrm{C} / \mathrm{N}$ ratio, faster is the decomposition process. Compared to the control, all treatments showed narrowing of $\mathrm{C} / \mathrm{N}$ ratio (Table 3). The lowest attained $\mathrm{C} / \mathrm{N}$ ratio of paddy straw was 15.6. Highest narrowing of $\mathrm{C} / \mathrm{N}$ ratio from 47.8 to 46.5 was seen in case of P1. A decrease in $\mathrm{C} / \mathrm{N}$ during composting may be attributed to transformation of organic carbon in to carbon dioxide and the corresponding increase in $\mathrm{N} \%$ [6]. In the present investigation, all the inoculated composts showed a $\mathrm{C} / \mathrm{N}$ ranging from 15.6 to 20.2; however, P1 compost recorded a relatively high $\mathrm{C} / \mathrm{N}$ ratio (Table 3). The total carbon content decreased in both inoculated and non-inoculated substrates during 12 weeks of decomposition. Microorganisms utilized C-compounds as their main energy source. Carbon content is lost during composting in the form of $\mathrm{CO}_{2}$ as metabolic end-product while total nitrogen content increase due to anabolism of cell structure, enzymes, hormones [8]. The increase of total nitrogen content during composting was in the agreement with other studies [6, 8]. Germination index (GI) is the most sensitive parameter used to evaluate the phytotoxicity of composts for seedling emergence. Phytotoxicity was conducted using seeds of Lepidium sativum. GI values for different composts ranged from $95-175 \%$ (Table 3 ).

The composition of humic and fulvic acid in the compost samples indicated the composting process was completed and was ready for application in agricultural lands. Determination of humic substances is one of the indices for maturity of compost. Humic substances including humic acid (HA) and fulvic acid (FA) increases as the composting progresses and hence are used for evaluating maturity of the compost. In all the five treatments, HA and FA was present in significant amounts in $\mathrm{P} 3$ and $\mathrm{P} 5$ respectively. 
The content and chemical forms of phosphorus $(\mathrm{P})$ in compost are essential variables for its proper management. Dehydrogenases are a fundamental part among the intracellular metabolites present in microorganisms; primarily responsible for respiratory metabolic activities, it behaves as an indication of the redox system of microorganisms as the enzymes are primarily involved in transition of hydrogen atoms, thus acts as one of the criteria for measuring the active microbial biomass participating in the composting bioprocess.

Therefore dehydrogenase activity measures the total is used as one of the parameters for monitoring the maturity of compost [29]. Dehydrogenase was found to increase throughout the process indicating intensification of microbial activity. The dehydrogenase activity was highest in the first month of composting (Fig. 4). The dehydrogenase activity showed a downward trend with the maturity of composting upto 90 days.

\section{CONCLUSION}

The preliminary investigation for characterization of lignocellulose degrading bacteria and fungi demonstrates that out of 12 treatments studied under controlled conditions for optimization of inoculum dose, four treatments namely T6, T7, $\mathrm{T} 11$ and T12 were found best in terms of enzymes production and composting.

These treatments were further applied on large scale in composting pits. Among all the four treatments, the treatment T7 (P3) and T12 (P5) were found to be the best treatments as evaluated by physico-chemical and biochemical experimental procedures. As indicated from the maturity parameters T7 and T12 served as good amendments in agricultural lands.

These psychrotrophic microbial consortia can be used for composting of agricultural agri-residues, which helps in enhancing soil fertility and decreasing environmental pollution caused by burning of agri-residues.

\section{ACKNOWLEDGMENTS}

Authors acknowledge the support of ICAR- Indian Agricultural Research Institute, New Delhi for in house project on ex situ composting of agri-residues.

\section{DECLARATION}

The experiments undertaken comply with the current laws of India, the country where the investigation was undertaken. There are no conflicts of interest.

\section{REFERENCES}

1. Kadam, KL, Forrest, LH, Jacobson, WA. Rice straw as a lignocellulosic resource: collection, processing, transportation, and environmental aspects. Biomass Bioenerg. 2000; 18: 369-389.

2. Gadde, B, Bonnet, S, Menke, C, Garivait, S. Air pollutant emissions from rice straw open field burning in India, Thailand and the Philippines. Environ Poll. 2009; 157: 1554-1558.
3. Hatamoto, M, Tanahashi, T, Murase, J, Matsuya, K, Hayashi, M, Kimura, M, Asakawa, S. Eukaryotic communities associated with the decomposition of rice straw compost in a Japanese rice paddy field estimated by DGGE analysis. Biol Fert Soils. 2008; 44: 527-532.

4. Ahmad, R, Jilani, G, Arshad, M, Zahir, ZA, Khalid, A. Bio-conversion of organic wastes for their recycling in agriculture: an overview of perspectives and prospects. Ann Microbiol. 2007; 57: 471-479.

5. Blackmore, E, Keeley, J. Assessing the benefits of sustainability certification for small-scale farmers in Asia. IIED Natural Resource Issues, London. 2012.

6. Kumar, A, Gaind, S, Nain, L. Evaluation of thermophilic fungal consortium for paddy straw composting. Biodegradation. 2008; 19: 395-402.

7. Sharma, RK, Arora, DS. Biodegradation of paddy straw obtained from different geographic locations by means of Phlebia spp. for animal feed. Biodegradation. 2011; 22: 143-152.

8. Kausar, H, Sariah, M, Saud, HM, Alam, MZ, Ismail, MR. Isolation and screening of potential actinobacteria for rapid composting of rice straw. Biodegradation. 2011; 22: 367-375.

9. Barrington, S, Choinière, D, Trigui, M, Knight, W. Effect of carbon source on compost nitrogen and carbon losses. Bioresour Technol. 2002; 83: 189-194.

10. Hassen, A, Belguith, K, Jedidi, N, Cherif, A, Cherif, M, Boudabous, A. Microbial characterization during composting of municipal solid waste. Bioresour Technol. 2001; 80: 217-225.

11. Yadav, AN, Sachan, SG, Verma, P, Tyagi, SP, Kaushik, R, Saxena, A. Culturable diversity and functional annotation of psychrotrophic bacteria from cold desert of Leh Ladakh (India). World J Microbiol Biotechnol. 2015; 31: 95-108.

12. Yadav, AN, Verma, P, Kumar, M, Pal, KK, Dey, R, Gupta, A, Padaria, JC, Gujar, GT, Kumar, S, Suman, A, Prasanna, R, Saxena, AK. Diversity and phylogenetic profiling of niche-specific Bacilli from extreme environments of India. Ann Microbiol. 2015; 65: 611-629.

13. Zhou, X, Chen, H, Li, Z. CMCase activity assay as a method for cellulase adsorption analysis. Enzyme Microb Tech. 2004; 35: 455 459.

14. Wejse, PL, Ingvorsen, K, Mortensen, KK. Purification and characterisation of two extremely halotolerant xylanases from a novel halophilic bacterium. Extremophiles. 2003; 7: 423-431.

15. Miller, GL. Use of dinitrosalicylic acid reagent for determination of reducing sugar. Analyt Chem. 1959; 31: 426-428.

16. Yadav, AN, Sachan, SG, Verma, P, Kaushik, R, Saxena, AK. Cold active hydrolytic enzymes production by psychrotrophic Bacilli isolated from three sub-glacial lakes of NW Indian Himalayas. J Basic Microbiol. 2015; doi:10.1002/jobm.201500230.

17. Suman, A, Verma, P, Yadav, AN, Saxena, AK. Bioprospecting for extracellular hydrolytic enzymes from culturable thermotolerant bacteria isolated from Manikaran thermal springs. Res J Biotechnol. 2015; 10: 33-42.

18. Verma, P, Yadav, AN, Khannam, KS, Kumar, S, Saxena, AK, Suman, A. Molecular diversity and multifarious plant growth promoting attributes of Bacilli associated with wheat (Triticum aestivum L.) rhizosphere from six diverse agro-ecological zones of India. J Basic Microbiol. 2016; 56: 44-58.

19. Yadav, AN, Sachan, SG, Verma, P, Saxena, AK. Prospecting cold deserts of north western Himalayas for microbial diversity and plant growth promoting attributes. J Biosci Bioeng. 2015; 119: 683-693.

20. Verma, P, Yadav, AN, Khannam, KS, Mishra, S, Kumar, S, Saxena, AK, Suman, A. Appraisal of diversity and functional attributes of thermotolerant wheat (Triticum aestivum L.) associated bacteria from peninsular zone of India. Saudi J Biol Sci. 2016. doi:10.1016/j.sjbs.2016.01.042.

21. Shukla, L, Senapati, A, Tyagi, S, Saxena, AK. Economically viable mass production of lignocellulolytic fungal inoculum for rapid degradation of agrowaste. Curr Sci. 2014; 107: 1701.

22. Walkley, A, Black, IA. An examination of the Degtjareff method for determining soil organic matter, and a proposed modification of the chromic acid titration method. Soil Sci. 1934; 37: 29-38. 
23. Black, C, Evans, D, White, J, Ensminger, L, Clark, F. Method of soil analysis. Part II. Am Soc Agron, Madison, USA. 1965; 1572.

24. Zucconi, F, Monaco, A, Debertoldi, M. Biological evaluation of compost maturity. Biocycle. 1981; 22: 27-29.

25. MacGregor, S, Miller, F, Psarianos, K, Finstein, M. Composting process control based on interaction between microbial heat output and temperature. Appl Environ Microbiol. 1981; 41: 1321-1330.

26. Paredes, C, Roig, A, Bernal, M, Sánchez-Monedero, M, Cegarra, J. Evolution of organic matter and nitrogen during co-composting of olive mill wastewater with solid organic wastes. Biol Fert Soils. 2000; 32: 222-227.

27. Chaturvedi, S, Kumar, A, Singh, B, Nain, L, Joshi, M, Satya, S. Bioaugmented composting of Jatropha de-oiled cake and vegetable waste under aerobic and partial anaerobic conditions. Journal of basic microbiology. 2013; 53: 327-335.
28. Rashad, FM, Saleh, WD, Moselhy, MA. Bioconversion of rice straw and certain agro-industrial wastes to amendments for organic farming systems: 1. Composting, quality, stability and maturity indices. Bioresour Technol. 2010; 101: 5952-5960.

29. Barrena, R, Vázquez, F, Sánchez, A. Dehydrogenase activity as a method for monitoring the composting process. Bioresour Technol. 2008; 99: 905-908.

\section{How to cite this article:}

Shukla L, Suman A, Verma P, Yadav AN, Saxena AK. Syntrophic microbial system for ex-situ degradation of paddy straw at low temperature under controlled and natural environment. J App Biol Biotech. 2016; 4 (02): 030-037. DOI: 10.7324/JABB.2016.40205 